\title{
Palabras del fondoy grados de peligrosidad: la filosofía nietzscheana en Los siete locos y Los Lanzallamas de Roberto Arlt
}

Fecha de recepción: 23 de noviembre de 2018

Fecha de aprobación: 25 de marzo de 2019

\section{Resumen}

Este artículo reflexiona en el presupuesto de que el escritor argentino Roberto Arlt fue un incansable lector de la filosofía del alemán Friedrich Nietzsche, y que en sus novelas Los siete locos y Los lanzallamas se establece una profunda relación con el pensamiento filosófico de Nietzsche. Seguidamente, el artículo reflexiona sobre los alcances, la permeabilidad y las contaminaciones presentes en las novelas, Los siete locos y Los lanzallamas, profundizando en las oportunidades creativas y literarias de su narrativa, así como en sus imágenes del lenguaje. Finalmente, se estudia el influjo de presupuestos nietzscheanos como la posibilidad de transgresión, la agresión en el lenguaje, la transvaloración y las relaciones de fuerzas, que permean el sentido de lo trágico y lo condensan desde la no-genialidad de la novelística arltiana.

Palabras clave: crítica literaria, novela latinoamericana, Roberto Arlt, pensamiento trágico, filosofía nietzscheana.

Citar: Niño Arteaga, Y. (julio- diciembre de 2019). Palabras del fondo y grados de peligrosidad: la filosofía nietzscheana en Los siete locos y Los Lanzallamas de Roberto Arlt. La Palabra, (35), 83-99. 아 https://doi.org/ 10.19053/01218530. n35.2019.8869

\section{Yesid Niño Arteaga}

Universidad de Nariño

Estudiante de Doctorado en Ciencias de la Educación, Red de Universidades Estatales de Colombia; Magíster en Etnoliteratura y Licenciado en Filosofía y Letras, Universidad de Nariño. Docente de Formación Humanística, Universidad de Nariño. (๑) https://orcid. org/0000-0002-5628-8854

yesidnio@hotmail.com

* Artículo de reflexión derivado de la investigación en curso "Novela urbana y cuerpos transgresores: la ciudad y el cuerpo en la novelística de Roberto Arlt, Andrés Caicedo y Rafael Chaparro Madiedo". 


\section{la palabra}

\section{Words from the Background and Degrees of Danger: the Nietzsche's Philosophy in Los siete locos [The Seven Madmen] and Los Lanzallamas [The Flamethrowers] by Roberto Arlt}

\section{Abstract}

This article reflects on the assumption that the Argentine writer Roberto Arlt was a persistent reader of Friedrich Nietzsche because in the novels Los siete locos [The Seven Madmen] y Los lanzallamas [The Flamethrowers] Arlt establishes a deep relationship with Nietzsche's philosophical thought. In this way, the article establishes the impact and the scope of the novels studied and explores into its creativity and Roberto's Artl narratives techiniques. Finally, the article studies why the fiction of Roberto Arlt is conceived under the influence of Nietzsche's philosophical thought such as the possibility of transgression, aggression in language, transvaluation and the relations of forces, which permeate the meaning of the tragic and the non-genius contained in these novels by Roberto Arlt.

Keywords: literary criticism, Latin American novel, Roberto Arlt, tragic thought, Nietzschean philosophy. 


\section{Introducción}

En la obra literaria de Roberto Arlt (1900-1942), se examina lo humano en su dimensión agresora por medio de la apertura y la afirmación de la intensidad creadora. En las "Palabras preliminares" a Los lanzallamas el autor manifiesta que la creación literaria constituye una acción casi ambigua que trata con condiciones humanas, como la pena, la rudeza, la obstinación y la agresión, puesto que la creación está por fuera de la normalidad, constituyéndose en un «lujo» para el que decide interferirse a sí mismo a partir de la soledad y el recogimiento. Ese lujo, que ronda en lo excéntrico, debe ser visto en esas condiciones como reconocimiento de la voluntad creadora y arrojo a la posibilidad horizontal del alma, que lleva el peso de la vida y de la muerte en ese constante empalabramiento que Arlt evoca como el grado de peligrosidad que se hace definitivo para vivir.

En la novelística de Roberto Arlt, la escritura como actividad creadora, que contiene la "materia explosiva necesaria" (Nietzsche, 2000, p. 646), reviste su precipicio en la dislocación, el diálogo, la experiencia, y la lectura. El uso de recursos literarios como la exuberancia de hi- pérboles, del hipérbaton $\mathrm{o}$ el gerundio, de analogías, de metáforas largas, la intromisión de conceptos filosóficos, de referencias bíblicas, de descripciones del escenario periodístico o del vocabulario de las ciencias naturales, según el escritor Juan Carlos Onetti, que conoció personalmente a Arlt, hace que su trabajo novelístico se pueda apreciar como una propuesta literaria instintiva y renovadora, puesto que Arlt personificaba un "nuevo tipo de escritor", que procura examinar enérgicamente "el desmoronamiento del espacio social y no tenía tiempo para detenerse en el artesanado del estilo" (Onetti citado en Cervera, 2009).

Figuras como Julio Cortázar y Juan Carlos Onetti dedican ensayos a Arlt. Onetti escribe un texto denominado "Semblanza de un genio porteño"1, más tarde incluido como prólogo a Los siete locos en la edición de 1981, y que acabó convirtiéndose en un verdadero bebedizo para conocer la narrativa arltiana, pues sin ningún temor el mismo novelista uruguayo considera la obra de Arlt como determinante para su trabajo como escritor, y quizás crucial para la literatura latinoamericana por venir.

El presente artículo profundiza en el presupuesto de que el escritor Roberto Arlt fue un asiduo lector de la filosofía nietzscheana, y que las novelas de Arlt Los siete locos y Los lanzallamas muestran una profunda relación con el pensamiento de lo trágico, expuesto principalmente por la filosofía de Nietzsche. Igualmente, el artículo muestra que estas dos novelas profetizan, desde la oportunidad de la ficción, del posible futuro compuesto por las atrocidades de los fascismos y comunismos de la primera mitad del siglo XX, tal como lo confirma Amícola (1994), pero también representan una brutal crítica a los modos de vida capitalistas y al expansionismo tecnológico y financiero que acaeció en Latinoamérica durante el inicio del siglo XX. Según Piglia (2000), la "marca" de Nietzsche en la obra arltiana es muy "nítida". En ella se encuentra la posibilidad de transgresión, la relación con el erotismo, la idea de las transvaloraciones, las relaciones de fuerzas, así como el sentido de lo trágico. Estos elementos de la filosofía nietzscheana ayudan a condensar la pregunta: ¿Qué matices y contaminaciones, así como elementos poéticos, filosóficos y litera-

En algunos casos, este texto de Onetti suele nombrarse como "Semblanza de un genio rioplatense" (Cervera, 2009). 
rios, puede brindar el estudio de esta influencia-deslizamiento, entre la escritura filosófica nietzscheana y novelística arltiana?

De hecho, es el mismo Roberto Arlt quien en 1930, en el texto "La inutilidad de los libros" derivado de sus conocidas "Aguafuertes porteñas", exterioriza la conciencia de estar trabajando incesantemente en su novela Los lanzallamas; pero, al mismo tiempo, logra expresar parte de esa "angustia de la influencia", que años más tarde teorizaría Harold Bloom: "la gente recibe la mercadería y cree que es materia prima, cuando apenas se trata de una falsificación burda de otras falsificaciones, que también se inspiraron en falsificaciones" (Arlt, 2014, p. 34 ). De allí que sea válido mostrar las superficies o siluetas de la influencia nietzscheana, sobre todo de Asi hablaba Zaratustra, en las novelas Los siete locos y Los lanzallamas de Roberto Arlt, con el propósito de sopesar-reflexionar en el poder de asimilación y contaminación dentro de esos tejidos desde una reciprocidad estética (Bloom, 1995; 2011). Precisamente, porque la labor de la estética permite una abundancia en el sentido, pero también la intrusión en el error y en el sufrimiento (Bloom, 2005); mezcla de conciencia y de recursos vitales y literarios que la obra de Nietzsche pudo haber estimulado en el proceso creativo, en las imágenes del lenguaje y en la apertura filosofía-literatura/literatura-filosofía reinante en $L o s$ siete locos y Los lanzallamas, situación que permite que dentro del artículo se procure desplegar posibles tejidos de crítica cultural, como sendero de esta reflexión que se centra en la literatura (Spivak, 2009).

\section{El pensamiento de lo trágico como posibilidad del espacio literario}

La obra de los grandes autores quizás pueda verse como una constante apuesta por la vida. Los matices de oscuridad y de locura se hacen precisos para repensar la multiplicidad contenida o que se desprende de la vida. Es en ese sendero que, en Los siete locos y en Los lanzallamas, novelas escritas por el escritor argentino Roberto Arlt (1900-1942), no se puede dejar a un lado o desatender la posibilidad transgresora de lo literario (Bataille, 2015), la búsqueda del simple propósito de apartar la elegancia intelectual y reírse de los rótulos: artista, genio, sabio, como intensión, mientras se escribe, para afirmarse en la intempestividad, y así tal vez, lograr fisurar al momento racional, pero manteniendo el proceso creativo ante cualquier circunstancia.

La imagen del escritor en Roberto Arlt, supone fisuras frente a lo que en cualquier momento se podría llamar literatura edificante o que aspira a una imagen por entero positiva del mundo o que cae en una trivial felicidad. Incluso, la imagen de mal escritor es sometida a crítica por el mismo Roberto Arlt como escritor, quien pone a prueba toda condición del ser en la ardua tarea de escribir como acción inevitable para vivir dentro del mundo social, pero dentro de la afirmación vital que supone una única dimensión de la vida, que es el tiempo. Es así que, su estilo se hace difícil, porque muestra la simple temporalidad del ser humano, usa un lenguaje no trascendente sino inmanente, exterioriza las prácticas del lenguaje y su palabrerío que se encuentran por fuera de las formas comunes de una racionalidad logocéntrica, pero que no vincula al pensamiento con el dolor.

Es por eso que, resulta insostenible que la novelística de Roberto Arlt sea catalogada como la de un escritor menor, su influencia en las literaturas posteriores no solamente argentinas, sino latinoamericanas, es indiscutible, y las recelosas críticas que lo catalogan como un escritor "advenedizo", "naif" o "semianalfabeto" ya resultan totalmente desafortunadas (Goloboff, 2002); puesto que la narrativa arltiana traza puentes con filosofías de pensadores como Schopenhauer, Nietzsche, Saint-Simon, Nordau, Stuart Mill y De Quincey, profundamente con la obra de Dostoievski (Amícola, 1994), pero 
también con la obra de escritores y poetas como Baudelaire, Novalis, Verlaine, Poe, Cervantes, Flaubert, Whitman, Wilde, Valle Inclán, Gorki, Quevedo (Goloboff, 2002, p. 112), y por supuesto, con los escritores de su época, como: Jorge Luís Borges, Elías Castelnuovo, Leónidas Barletta, Raúl González Tuñón, Roberto Mariani y Nicolás Olivari. $^{2}$

En el díptico ${ }^{3}$ que componen Los siete locos y Los lanzallamas, la novela se propone como creación intempestiva, con un estilo disidente. Para Roberto Arlt, esta obra será experiencia de ese lujo, que implica crear en condiciones adversas para el escritor. Adversidad o sufrimiento que rodea el vivir de las personas en la sociedad del capitalismo instantáneo y su seca pauta de civilización mercantil que repudia la ficción (Arlt, 2008, p. 197), por eso estas dos novelas hacen parte de lo que Arlt acertadamente llamó como escritura que atraviesa redacciones estrepitosas. El diálogo entre crónica periodística y el acto de novelar, dispersa la misma invocación de la angustia, "sífilis arraigada hasta los huesos" (Arlt, 2015, p. 289), que los personajes en- trometen en su respiración alucinada cuando observan como única manera de realización de su ser dentro ese "tienes que sufrir" pintado en las paredes, en las mesas, en los escritorios, en los autobuses o en las camas. Sus personajes "quieren romper los moldes de la vida, viven angustiados, como si fuera ayer el día en que los echaron del paraíso" (Arlt, 2008, p. 278). El sufrimiento vivenciado por los personajes, produce una condición de fantasmas ${ }^{4}$ que se denigran para estallar sobre el presente.

El abrasamiento o la intolerancia de capítulos como el "El terror en la calle", "El trabajo de la angustia", de Los Siete locos o "El poder de las tinieblas" y "Las fórmulas diabólicas" de Los lanzallamas, son parte de posibles acaecimientos ficcionales que surgen en la mínima frecuencia, que no resulta quebrantada por los designios de los nuevos ídolos asentados en los emblemas del dinero. El sufrimiento dentro de la ciudad se describe mediante voces y verbos incidentes, precipicios, vidrios sanguinarios y sin filo, la huida de lo teórico y el inminente acceso al pabellón de la palabra grotesca, antes que santificada o habitual, puesto que en lo grotesco la palabra resulta desplomada, arrogante, humillante y humillada (Carbone, 2007). La escritura se hace en presente, así sea atravesando redacciones estrepitosas, para que la palabra emerja como lienzo acre frente a la distracción con el tiempo, que es producto del desmoronamiento de los edificios sociales.

En la novela de Arlt, la escritura tiene que lograrse así sea con la existencia apaleada, amarrada en la ciudad, así sea en medio de la hostilidad. El pensamiento de lo trágico es lo que permite la reconstrucción del presente. El pensamiento de lo trágico reconoce la perspectiva de lo real en su plena erupción. El pensamiento trágico no detiene ni obstaculiza el derrame de lo real, "no traza ningún plan para impedir que lo real sea" (Onfray, 2018, p. 34). En la novelística de Arlt, el lector puede darse cuenta de que lo que permanece en el tiempo es "una potencia que se revela multiforme, polimorfa" (Onfray, 2018, p. 34), que se impulsa al mismo tiempo como una desorientación o quebrantamiento desde

2 El propio Arlt realiza pequeñas críticas y comentarios a la obra de sus contemporáneos, y muestra cierta predilección agonística con la obra de los escritores del Grupo de Boedo (Goloboff, 2002).

3 Cabe mencionar que, es el mismo Arlt quien indica una posible división entre primera y segunda parte de una única obra: "Con Los lanzallamas finaliza la novela Los siete locos" (Arlt, 2008).

4 La condición de fantasma implica que cada sujeto crea guiones o relatos en los cuales deforma y se deforma, buscando siempre la realización de un deseo (Laplanche y Pontalis, 1981). Este significado sin duda es tomado de la tragedia shakesperiana, donde el fantasma emite duda al personaje de carne y hueso, es decir, puede ser tan real como no puede serlo. Situación visible en cada personaje de Los siete locos y Los lanzallamas, hay fantasmas que atormentan la percepción de la realidad, las acciones y los sueños de los personajes, proponiendo casi siempre proyecciones-lucha dentro de un futuro infernal o episodios donde los personajes se abandonan a la experiencia de lo grotesco (Carbone, 2007). 
la ficción. ¿Potencia poético-narrativa? ¿Potencia literaria? Por eso, la novelística de Arlt atiende el sentido de lo trágico desde lo literario, puesto que no se contenta con creer como lo hacen los fanáticos optimistas, pero tampoco con las redes de prejuicios y suposiciones de un pensamiento pesimista.

Para la filosofía de Nietzsche, lo trágico se dilata con la terribilidad, muestra su posibilidad de agresión y permite al pensamiento no caer en engaños, ya que las imágenes terribles proporcionan también la "alegría dionisiaca". La alegría es una constante que resulta de la emergencia de relaciones con el sentimiento de poder. La filosofía nietzscheana advierte que, gran parte de lo que se ha aprendido de lo trágico, desde los griegos, es un error, porque se tiende a implantar una "superficialidad moralística" que resulta siempre en el advenimiento del nihilismo o aspiración a la nada (Nietzsche, 2000, pp. 658-659). No se trata tanto de asumir el pensamiento de un Nietzsche que alaba el tipo humano del conquistador (Amícola, 1994), sino que lo humano tiene que adquirir otro sentido desde lo trágico, puesto que el sufrimiento, las privaciones y los desprecios más terribles permiten nuevos acrecentamientos de la felicidad en la disrupción del amor (Nietzsche, 2000, p. 659). Lo trágico se vincula al erotismo, porque son condicio- nes para el crecimiento de las fuerzas. Conocer todos los rincones del alma en lucha por la felicidad del amor, es parte de la sabiduría trágica.

Este otro sentido de lo trágico, del cual Nietzsche es su descubridor (Nietzsche, 2000; Onfray, 2018), permite abordar otras regiones del saber literario, y se puede relacionar con la novelística de Roberto Arlt a través de la iniciativa de transgresión, experiencia vinculada al erotismo como la "afirmación de la vida hasta en la muerte" (Bataille, 2007). Aunque Arlt hace uso de sutiles referencias, aunque no directas, a la filosofía nietzscheana, aparece el interrogante acerca de porqué transmitir esa filosofía a sus lectores. La pregunta radica en que si Arlt, dentro de su escritura casi frenética, esperaba llegar a una gran cantidad de lectores no académicos, ¿qué maquinación constituye presentar a este público porteño, mestizo, pobre, casi inculto, que está por fuera de los críticos académicos, una novela conjurada bajo la influencia filosófica de un escritor cuyo pensamiento se afirma en el sentido del dolor?, tal y como afirma Harold Bloom al respecto de la obra de Nietzsche.

Tal vez de eso trata el talento en el hecho de novelar, pero los personajes de Los siete locos y Los lanzallamas fagocitan las partículas de otra posibilidad de existencia literaria por medio del sentido de lo trágico, que puede entenderse como la total afirmación de lo real. Lo que lleva a re-crear, a complementar, a disidir, en una posición ininterrumpida y ruidosa-angustiante, la fuerza que expone la voluptuosidad de los cuerpos emitida desde la posibilidad de novelar: ¿Es posible expresar el ser y sentir lo misterioso del sí mismo a través de un crimen? (Arlt, 2015, p. 102); ¿la fábrica de fosgeno y gas mostaza para traer la revolución al mundo?, ¿el nombre de Augusto Remo Erdosain significa algo misterioso para el lector?, ¿el Rayo de la Muerte soñado por el Astrólogo es el arma que los gobiernos usarán contra toda resistencia social?, ¿la castración o la castidad, la estupidez o el fracaso, qué puede simbolizar mayor desprecio en una cultura judeocristiana-capitalista-nihilista y qué tanto hay de esta cultura en la ciudad de Buenos Aires de los primeros años del siglo XX, pero al mismo tiempo en un posible futuro de las ciudades de Latinoamérica?

Transvaloraciones: la confesión pagana, contra el nuevo ídolo, la experiencia del fondo

Como lo mencionó Arlt, "cuando se tiene algo que decir, se escribe en cualquier parte. Sobre una bobina de papel o en un cuarto infernal. Dios o el diablo están junto a uno dictándole inefables palabras" (Arlt, 2008, p. 9). Sobre esta "confesión paga- 
na", Arlt enseña que se escribe también para causar conmoción a los estados de firmeza de las creencias y las vivencias, por lo que Los siete locos y Los Lanzallamas vendrían a ser un sabotaje intelectual al sistema "civilizado", que ve su destino en extremo firme a través de la "educación capitalista", la cual se asienta en la instrucción de los sujetos como receptáculos a domesticar para una posible proliferación de las bombas y los gases (Arlt, 2008, p. 198).

El sabotaje a la "educación capitalista" (Arlt, 2008) se hace presente por medio de la sátira. Una narración satírica, que aún se enfrenta al advenimiento de los problemas que el trabajo de la creación literaria puede extraer de lo sociocultural, permite pensar modos de vida en sabotaje, que el Astrólogo, personaje que en estas novelas tiene gran relevancia, compone en desasosiego como proyecto de una antipedagogía de los pensamientos marginales e intolerables actos: microteorías de células guerrilleras, violencia imaginaria cuerpo a cuerpo, comercialización de cuerpos o propagaciones de prostíbulos, enseñanza y perfeccionamiento de herramientas mortales como gases bioquímicos para la guerra, claro está, lo anterior bajo la atractiva responsabilidad de la «utilidad social».

La narración satírica expresa en Los siete locos y en Los lanzallamas, las dinámicas del pensamiento que se ubican por fuera de la territorialidad capitalista, que plantea ordenaciones existenciales según criterios administrativos. Burla como parte de la terribilidad. A "la confesión pagana" (Nietzsche, 2000), Arlt la entiende en estas dos novelas desde la escritura filosófica de Nietzsche: se tiene que crear a toda costa un pensamiento, una literatura, que vaya más allá del bien y del mal, porque la literatura es lo único que puede superar el constante brote de excusas de lo humano ante un plano enteramente racional o enteramente teológico.

Arlt comprende que se hace literatura al escribir con sangre, a la manera nietzscheana, "quien escribe con sangre, y escribe sentencias, no ha de ser leído, sino aprendido de memoria" (Nietzsche, 2005, p. 44); aprende de la filosofía nietzscheana, que hay que mirar hacia abajo, puesto que se requiere amar la crueldad de la vida en el intento de vaciar lo humano, para ver qué queda más allá; se vacía de lo compasivo, busca la Naturaleza en medio del vaciamiento que implica la ardua cotidianidad dentro de la ciudad de la "supercivilización espantosa". El escritor logra reírse y elevarse desde el trabajo de la palabra literaria, incendia lo real con ficciones para sentenciar que "nadie puede defendernos de la Vida ni de la Muerte" (Arlt, 2008, p. 220), de allí que estas novelas sean un guerrear incesante, no solo con la realidad sino con la misma literatura, y se busque resaltar aquellos seres impávidos, burlones y violentos que aspiran también a la sabiduría y al amor. Por ejemplo, Erdosain, personaje protagonista de la obra, ya desde el inicio de Los siete locos se encuentra perdido dentro de un fraude y sabe que es tarde para cualquier tipo de arrepentimiento. Hay un «círculo de silencio y tinieblas» que se interpone en todo su presente e interrumpe la "continuidad de sus ideas" (Art, 2015, p. 12). Criminal incategorizable, suicida taciturno, intenta dispararse en la cabeza, pero no posee fuerzas ni tiempo. Lla-

$5 \quad$ Vale la pena resaltar que, a diferencia de Europa y Norteamérica, las ciudades latinoamericanas se adaptaron al desarrollismo industrial y urbano en la primera mitad del siglo XX, desde la dirigencia de las élites que vieron en este enfoque el programa preciso para asentar el modelo económico capitalista desde el auge de lo industrial y lo financiero (neoliberalismo). El progreso urbanístico de la ciudad de Buenos Aires, pero también su academicismo europeizante, su ofuscación, sin contar su casi negación, por el pueblo pobre, iletrado y mestizo, rodean el corajudo enfrentamiento de la novela arltiana con los modos de vida pequeño burgueses y su encierro en las dictaduras político-militares que se presentan en gran parte de las ciudades latinoamericanas de la época: "ciudades tremendas en cuyas terrazas cae polvo de estrellas, y en cuyos subsuelos, triples redes de ferrocarriles subterráneos superpuestos arrastran una humanidad pálida hacia un infinito progreso de mecanismos inútiles" (Arlt, 2008, p. 43). 
ma a su hogar una cárcel y solo hay lugar en su pensamiento para lo que pueda relacionarse con su desdicha. Una atmosfera de sueño, desprecio, ironía e inquietud lo hacen "circular a través de los días como un sonámbulo", se proyecta en lo real desde «la zona de la angustia»" (Arlt, 2015, p. 12). En Los lanzallamas, en el capítulo titulado "Los amores de Erdosain", el mismo personaje describe cómo

Lo aíslan del mundo las sucesivas envolturas perpendiculares de silencio, que caen fuera de él, una tras otra, con tenue roce de suspiro. Silencio y soledad. Él permanece allí dentro, petrificado. Sabe que aún no ha muerto porque la osamenta de su pecho se levanta bajo la presión de la pena. Quiere pensar, ordenar sus ideas, recuperar su "yo", y ello es imposible (Arlt, 2008, p. 42).

Escindiendo en la indagación filosófico-existencial que es provocada por las hendiduras literarias de la novela, los personajes entienden que, en las redes de la angustia, la realidad literaria se vivencia de una manera espectral-flotante y de una manera exploratoria en progresiones subterráneas. En la profundidad del criminal ejercitada por Erdosain, persiste un desdoblamiento espectral en el cual se le admite ver fracciones de su sufrimiento, "ser" a través de lo criminal, pero ensanchando esta dimensión en lo humano, en "el misterio de sí mismo", cuya disconformidad hace que Erdosain sienta que puede flotar, acción sublime que en la novelística arltiana es la experiencia de los sentimientos de la agresión y las proyecciones de mundos oníricos, que a personajes, como Erdosain y el Astrólogo, por ejemplo, le permiten resistir la desgracia desde una condición represiva.

La realidad vista desde una manera exploratoria-subterránea, se asume porque cada personaje puede palpar, arrastrar, certificar, en medio de temblores y aullidos esa "horrible profundidad en la que se encuentra sumergido" (Arlt, 2008, p. 42). La mayoría de los personajes de Los siete locos y Los Lanzallamas se encuentran sumergidos o hundidos en el lago acre del sí mismo, pero siempre bajo el flujo de otro, es decir, esa singularidad diabólica de personajes como Erdosain, el Astrólogo, Haffner, Elsa, Hipólita, quizás sea una manifestación de su penetración y resistencia en el erotismo, ya sea experiencial, dialógica u onírica, que muchas veces roza la introspectiva existencial o la confesión filosófica.

Al superar lo supuesto de la narración, existe la certeza, más que la duda, de que ningún personaje de Arlt se encuentra realmente solo, debido a que la realidad del lenguaje literario es la otredad, un territorio siempre compartido por el Yo y por el Otro (Bajtín, 2015); por eso, los personajes se otorgan su tiempo de dura soledad, pero hay interconexiones y flujos en las desolaciones, y desde luego, teniendo la multiplicidad del fracaso como condición de adversidad, pero a su vez como componente de una extraña alegría que a veces parece la "alegría dionisiaca" de Nietzsche. Por ejemplo, en Los siete locos en un diálogo entre Erdosain y Barsut el farmacéutico, que es su víctima elegida, fuerte, pero ingenua; se entabla una ilustre conversación como si realmente el propósito de una vida criminal no lo supiera ninguno, tocan animosamente temas bíblicos, monetarios y, por supuesto, eróticos. Erdosain le logra sacar información sobre la esposa, Barsut le dice con toda naturalidad que antes de ser su esposa, Hipólita, era una prostituta, y que se lo confesó en un momento de rabia, de repente, Erdosain pregunta:

— ¿Y cómo te va?

- Muy bien... La farmacia da setenta pesos diarios. En Pico no hay otro que conozca la Biblia como yo. Lo desafié al cura a una controversia y no quiso agarrar viaje.

Erdosain miró repentinamente esperanzado a su extraño amigo. Luego le preguntó:

— ¿Jugás siempre? 
- Sí, y Jesús, por mi mucha inocencia, me ha revelado el secreto de la ruleta (Arlt, 2015, p. 22).

La vitalidad de este primer rompimiento o de este repentino salto dentro del diálogo, tal vez reside en saber reírse del sí mismo, pero acompañado de alguien más. Dar y saber encontrar lo que el Otro requiere para continuar el decir, incluso el silencio como parte de esta experiencia, como lo muestran los personajes de Elsa o Hipólita, que son quienes afirman el silencio. Este diálogo entre los personajes se acompaña de este rompimiento con el tema o sentimiento, para introducir aspectos transgresores dentro del humor y la burla como forma de mantener la línea de la conversación ${ }^{6}$, que gira en torno a conocer más de Hipólita y su antigua profesión. Pero quizás esto también se relacione con una posibilidad de transvaloración. Arlt escribe sobre otra forma de respeto, de tolerancia, de armonía, de creencias, de moralidad, pero lo hace invirtiendo su carga de fuerzas, ¿cómo conseguir respeto desde el irrespeto?, ¿cómo conseguir tolerancia desde la intolerancia?, etc. Así inmortaliza destellos de la transvaloración nietzscheana como ningún otro autor de su época, y quizás, como ningún autor hasta ahora en Latinoamérica.

Se podría mencionar al respecto, que la novela de José Asunción Silva, De sobremesa, también proporciona varios referentes del in-flujo de la obra nietzscheana ${ }^{7}$, ya que en partes de su narración se logra discurrir en trazas de esta filosofía, por ejemplo: el Übermensch, que Silva desentraña desde las relaciones de fuerza de una mujer, pero también su interpretación sobre la posible peligrosidad y violencia en la creación. "Muertos los amos serán los esclavos los dueños y profesarán la moral verdadera en que son virtudes la lujuria, el asesinato y la violencia (Silva, 1996). Silva parece conocer que el porvenir se compone de otros valores hechos de movimientos espontáneos, nuevos y fuertes (Nietzsche, 2000, p. 646). Pero a diferencia de la novela de Silva, las novelas de Arlt desencumbran los nombres y valoraciones que considera falsos o que no permiten adquirir conciencia de sí mismo. Se resalta que ambos comparten la idea de que la literatura debe ser hecha por gente nueva con nuevas necesidades y, por tanto, con necesidad de nuevos valores (Nietzsche, 2000; Arlt, 2008).

Por otra parte, y volviendo a Los lanzallamas, Haffner o El Rufián melancólico, también dentro de un monólogo de la proyección de su ser criminal, traza suposiciones sobre lo anterior, pero esta vez, opresivas, con intención de darse algo qué alcanzar dentro del mundo de la administración del negocio de la prostitución: "Por las tres mujeres me darían volando diez mil pesos. Todo esto es descabellado. Ilógico. Y yo soy un hombre lógico, positivo. Plata en mano y culo en tierra" (Arlt, 2008, p. 81). Haffner reluce en todo momento su carácter hastiado de un clásico ex-profesor de matemáticas. Los números, las fórmulas, la ironía y el desasosiego serán una constante en sus divagaciones. Nunca de acuerdo con el proyecto el Astrólogo, a pesar de estar rodeado de ellos y su contraparte, el Rufián melancólico reprime en su conciencia que está en oposición de la gloria y el poder, pero también expresa que está en rotunda contradicción con los filósofos y las prostitutas. Es un escéptico, un irónico y un

$6 \quad$ Este tipo de rompimientos es evidente en gran parte de los diálogos, así como en varios capítulos de las dos novelas estudiadas en el artículo.

7 La novela De sobremesa, del colombiano José Asunción Silva, publicada de manera póstuma en 1925, puede ser considerada como parte de esa escritura que trasciende con lo estrepitoso y tormentoso del trabajo creativo. La leyenda murmurada por Vallejo (2008), dice que Silva tenía varias obras escritas y que en el naufragio en el Caribe se hundieron los únicos manuscritos que Silva poseía y de los cuales esperaba realizar una posible publicación. Según Vallejo, luego de ese suceso, Silva escribió De sobremesa de manera frenética, diremos así: tejiendo retazos de memoria, de su ser, de ira y de océano. 
déspota que aborrece el poder, que expresa la desconfianza de una «perspectiva realista» de un personaje sobre las acciones enajenadas, controversiales o grotescas de otros personajes (Carbone, 2007). La ironía, según el romanticismo de Schlegel, figura en el contexto ontológico de la arbitrariedad. Presupone la elevación y una liberación del Yo sobre los prejuicios, objetivaciones, normas y valores. Pero, esa arbitrariedad si se la concibe como cualidad, supone una afinación o la vivificación permanente del deseo.

Es constante que en la obra de Arlt, las relaciones de lo humano con el dinero establecen, no solo un reflejo, sino el tránsito visto desde lo ficcional del proyecto nihilista de ese "nuevo ídolo" que es denunciado por Zaratustra (Nietzsche, 2005), como una monstruosidad: el Estado esboza el signo de la "voluntad de morir" por medio del fanatismo a sus "entrañas postizas", junto con la propagación del culto de la compra-venta, que resulta en el torniquete capaz de enajenar a las almas superfluas. Lo superfluo como lo que ya no puede acumular ni acrecentar fuerzas, lo que ya no dispone de la "materia explosi- va necesaria" (Nietzsche, 2000, p. 646).

Por el contrario, los personajes de la novelística arltiana no son para nada superfluos, en la medida en que sufren "el agobio de los viejos valores", pero al mismo intentan carcomer ese sufrimiento. Por eso, tanto Nietzsche como Arlt, son visionarios que van en contra de una falsa vida establecida en el indiviso nuevo ídolo que surge a través de la correspondencia entre política, dinero, guerra $\mathrm{y}$ modos de miseria. Hay una contradicción entre falsedad y fabulación, la primera apunta a las desdichas de un contexto social, mientras la segunda es capacidad de invención, reseña de la obra nietzscheana puesta en obra por Arlt.

En Arlt, la exploración del fondo del alma, pero también el bajo fondo de la ciudad, será el espacio inmanente para mostrar ese artificio diabólico que se gesta en la cotidianidad de sus personajes. Hay una voz, a la manera del daimón socrático, que susurra en Arlt la peligrosidad de las "inefables palabras". El fondo es la figura de la periferia, el elemento de unión entre la literatura y la oscuridad, propia de ese espacio que se difunde como recurso y sentimiento.
En el fondo se posibilita el ruido, la oposición, el deshecho, pero también la atracción, la complejidad, el salto y la diseminación. Quizás no hay otro aspecto que exteriorice esa comprensión del pensamiento de lo trágico, como la crítica a la falsa vida basada en nuevos fanatismos; crítica que, dentro de estas dos novelas de Arlt, sin duda, parece una clara influencia de la filosofía nietzscheana. Como si la angustia, el silencio y la soledad se parecieran a los símbolos de una poética baudelariana, pero en el contexto de un Zaratustra que ve en estos elementos de la realidad del ser, una condición para perder toda suerte de altura o de bajeza, lo que le permite recorrer el camino que lo lleva a sí mismo a su final, la horizontalidad del alma, que por terrible que sea, tiene el único deber de ser vislumbrada.

“¡Sentimientos hay empeñados en matar al hombre solitario! Si no lo logran, jellos mismos tienen que morir! Pero, ¿eres capaz de ser un asesino?" (Nietzsche, 2006, p. 70). Al igual que Nietzsche y Baudelaire, Arlt se encuentra atraído ardientemente hacia la belleza (Artl, 2008, p. 10), es decir, desde una perspectiva estética, literaria y nunca sistemática: no ve otro camino para vivir, sino el crear 
sin importar que arribe el fracaso. Y de allí su famoso "que los eunucos bufen", que evoca la "primera ley" de la voluntad creadora hecha por el poeta $\mathrm{Ru}$ bén Darío, para corroborar la afirmación del trabajo creativo como experiencia, prolongación, resistencia. "Y la primera ley, creador: crear. Bufe el eunuco: cuando una musa te dé un hijo, queden las otras ocho en cinta" (Rubén Darío, 1901, p. 50).

Grados de peligrosidad, personajes, ficciones y filosofías

La novelística arltiana tiene como pieza elemental, su relación con la agresión y la violencia. Las imágenes del lenguaje fisuran al mismo lenguaje como agobiantes explosiones o intermitencias de un delirio vital, se posibilitan rasgos o descripciones para que la ficción por medio del tratamiento de las circunstancias reales, las jugadas y la crueldad de todos contra todos, traduzca un "espectro de claridad", que puede parecer el mismo tiempo y espacio del lector como "tiempo soñado" o "tiempo que habría podido ser" (Blanchot, 2005, p. 196). Violencia sobre el tiempo que vincula, aleja y dispersa los fragmentos de la libertad y el porvenir. Agresión como posibilidad de romper todo equilibrio y lograr acrecentamiento de fuerzas.

En Los siete locos, la agresión se exterioriza como inevitable experiencia. In-experiencia que se asume en la novela como lugar donde se puede hacer extensiones y repliegues. Pero, al contrario, la violencia no solo es descripción de una posible crueldad política, religiosa, dogmática, militar ante lo humano; en Arlt, la violencia evoca el forcejeo con la tecnicidad, todavía más con el remedo de los estilos del «buen escritor» (delicado en la ensoñación sutil o providencial). Al contrario, Arlt se invita a sí mismo a roer estilos. Lo que sugiere descubrimientos y asechos. La creación en la novela, para Arlt, es un lienzo panorámico compuesto de fatigados colores sobre la siniestra capa de lo tangible, donde "no es posible pensar en bordados" (Arlt, 2008, p. 10), no se puede ser razonable ante el paulatino clamor o suplicio de cada individuo en cualquier sociedad. Por eso, la política, la religión, la economía y el desa- rrollismo tecnológico aparecen en Arlt como planos de locura, planos esquizoides y transgresores-a-transgredir. La fuerza de la agresión como lo que permite el desencadenamiento del ser, ese ser que, en la busca trágica del acrecentamiento de fuerzas, suscita la posibilidad de torrente, de estallido y de grito (Bataille, 2015). En otras palabras, si para Borges la novela era algo exageradamente ineficaz, la novela para Arlt expresa la contundencia para extender la detracción ante lo eficaz o lo útil. Para la novelística arltiana, no es posible que el ser humano pueda evitar la molestia de la literatura.

Las imágenes del lenguaje en Los lanzallamas permiten vivenciar geometrías diabólicas, fluctuantes, inhumanas, puntos, despliegues, verticalidades que se abalanzan al horizonte: "franja de sol y de mañana", siendo perseguida por una "oscuridad demencial". Así lo exterioriza el diálogo entre Hipólita y el Astrólogo:

Yo quiero que sea futuro. Futuro en campo verde, no en ciudad de ladrillo. Que todos los hombres tengan un rec-

8 Arlt reniega de esa especie de fanatismo que la crítica y los académicos de su época establece con la obra de Joyce, que, en su tiempo, aún no ha sido traducida al castellano (Arlt, 2008, p. 10). Siendo Joyce un escritor profundamente vinculado al trabajo del estilo dentro de su obra, Arlt dice no tener tiempo para establecer conversaciones de sobre literatura ni tener las "comodidades" para ser un trabajador del estilo. Aunque a pesar de su sonado desorden ortográfico, Artl la escribe entre comillas la famosa metáfora sobre los académicos castrados, quizás de manera distintiva, dando evidencia de la posible influencia crítica y literaria para su obra que fue la poética de Rubén Darío. De allí, el estilo intempestivo de Arlt, que busca la expresión poética del modernismo y de la vanguardia, pero estallado y extendido en la técnica de una prosa no por entero modernista ni tampoco completamente impersonal-experimental, pero sí en complicidad con ciertos aspectos de la filosofía nietzscheana. 
tángulo de campo verde, que adoren con alegría a un dios creador del cielo y de la tierra. -Cerró los ojos; Hipólita lo vio palidecer; luego se levantó, y llevando la mano al cinturón dijo con voz ronca: -Vea.

Se había desprendido bruscamente el pantalón. Hipólita, retrayendo el cuello entre los hombros, miró de soslayo el bajovientre de aquel hombre: era una tremenda cicatriz roja. (Arlt, 2008, p. 34).

¿Qué clase de peligro se logra con adelantarse al supuesto de que el origen de la maldad de un personaje sea producto de una castración abusiva? El peligro no está más allá del lenguaje, sino dentro de su existencia. Tanto para Lacan como para Žižek, en el lenguaje no existe una "intersubjetividad igualitaria", no hay equilibrio entre subjetividades, ni un por qué o para qué justificar con razones las afirmaciones del Otro. La agresión es parte vital de la existencia. En lugar de ejercer violencia directa sobre otro, se busca una confrontación, un debate, un intercambio de palabras, "y tal intercambio, incluso cuando es agresivo, presupone un reconocimiento mínimo de la otra parte" (Žižek, 2009, p. 78).

La peligrosidad puede ser una señal de esa elevación o esa capacidad de flotar, que caracteriza a los personajes arltianos, cuyo aire entonces vendría a ser la agresión; es decir, toman o adquieren una perspectiva de observación distinta, para así comprender que la imperfección y los sufrimientos son "parte de las cosas que más deben desearse" (Nietzsche, 2000, p. 645). La peligrosidad entonces es una posibilidad para el reconocimiento de los sentimientos afirmativos. La peligrosidad remite a la "la energía que puede descargarse como el relámpago y la conciencia de peligros mortales que resultan de las descargas de energía" (Bataille, 2015, p. 61).

La escritura se percibe en $L o s$ lanzallamas como exigencia de lo creativo en la fortaleza de poder retener la voluntad de trabajo y así narrar, pero también filosofar, desde el rompimiento que provoca la literatura, sobre las condiciones humanas e inhumanas. El proceso técnico del novelista exige soledad y recogimiento. No es posible encontrar la felicidad sino entre lágrimas (Arlt, 2008, p. 235). A propósito, Bataille (2007) sostiene que solo el horror o la prohibición descubre una elección, negativa o positiva, que permite entender que toda comprensión del ser se excita en lo prohibido. Para los personajes arltianos, la transgresión de las normas sería inconcebible si no existieran las innumerables prohibiciones propuestas por los demás. La transgresión y la ironía son elementos de la fabulación arltiana, porque en ellos lo real sigue su recorrido y se ofrece y se extiende en su brusca compenetración con la ficción. En palabras del Rufián melancólico:

\begin{abstract}
No, no, la vida tiene que ser otra. Lo evidente es su crueldad. Unos se comen a los otros. Es lo evidente. Lo real. Los únicos que escapan a esta ley de ferocidad son los ciegos y los locos. Ellos no devoran a nadie. Se les puede matar, martirizar. No ven nada los pobrecitos. Oyen los ruidos de la vida como un encalabozado la tormenta que pasa (Arlt, 2008, p. 86).
\end{abstract}

La imperfección y el sufrimiento son condiciones que los personajes arltianos llevan dentro de sí, condiciones de existencia y grados de peligrosidad, de allí que, ante el exceso de disconformidad, puedan flotar y hasta desagarrarse en proyecciones psíquicas o en alborotos causados por la transgresión. El parecer de Hipólita: “A veces me parece un mal sueño esta vida. Ahora que me siento tuya me aparece otra vez la pena de otros tiempos. Siempre, en todas partes, sufrimientos" (Arlt, 2015, p. 285), por ejemplo, su desmoronamiento de la idea del amor, el asesinato de su marido, el nuevo amorío con Erdosain, complementan las muestras del amor humano no desde su espiritualidad ingenua, sino desde las formas más siniestras de su pasión terrible (Arlt, 2015, p. 287). Incluso, en sus personajes Arlt busca otro sentido de lo 
femenino, la mujer como "principio y fin de la verdad" (Arlt, 2008, p. 35), busca una transvaloración a la individualidad y al sentido de "mujer" que parece entenderse según el creciente capitalismo y el propenso machismo de la época.

Cobarde, astuto, mezquino, lascivo, escéptico, avaro y glotón, del hombre actual no debemos esperar nada. Hay que dirigirse a las mujeres; crear celular de mujeres con espíritu revolucionario, introducirse en los hogares, en los normales, en los liceos, en las oficinas, en las academias $\mathrm{y}$ en los talleres. Solo las mujeres pueden impulsarlos a estos cobardes a rebelarse (Arlt, 2008, p. 35).

Por eso, personajes como Elsa e Hipólita, a pesar de la violencia a la que son objeto, son los únicos personajes seguros de sí mismas. Para Arlt, no hay más idealidad de lo bello que el cuerpo de la mujer. Fuera del cuerpo no queda sino la ruina: las alucinaciones de Ergueta con un Jesús mezquino que ama a los apostadores; Hipólita que en su juventud fue prostituta y ahora es ama de casa, pero la entristece su pasado; el Rufián melancólico al frente del negocio de la prostitución y sus dilemas morales e inmorales; el Buscador de oro, su frialdad y su preferencia por el dinero; la deformidad, la astucia y la manipulación del otro en el Astrólogo; el sadismo y el carácter convaleciente de Erdosain. Todo final se entiende dentro del espectro y el tanteo subterráneo del sí mismo, Erdosain lo sabía desde el principio, solo que aún no tenía las fuerzas requeridas para observar su eclipse. Por eso, una de las preguntas ante el suicidio de Erdosain puede ser: ¿por qué dejar que el hombre de la mentira, el Astrólogo, soñador-castrado, idealista colosal, compositor de la Sociedad secreta de crimen, se mantenga todavía con vida y quizás con nuevos proyectos? Esa no-genialidad de Arlt, que niega la misma genialidad, permite astuta y maliciosamente que la respuesta se configure en los temblores que asedian la integridad del lector.

\section{La no-genialidad arltiana}

Arlt sabe ${ }^{9}$ que la mayor parte de la crítica literaria de su tiempo, que también hace parte de esa "burda comedia" de la moralidad del pequeño burgués que se la pasa construyendo ideas a lo inglés o a lo francés sin lograr ver la vida ni el trabajo del lenguaje que pasa a su lado, no posee un pensamiento distinto a un pensamiento de "iniciados" que emite prontas respuestas para satisfacer el estricto criterio de las "personas honorables" (Arlt, 2008). Para Arlt, la activi- dad crítica es también parte de la literatura, por tanto, no tiene otro deber sino el de participar de la disolución de las "columnas de la sociedad", de fatigar los salones de la injusticia, de la opresión y de lo aparentemente correcto.

Parece un desatino aseverar que en Arlt hay una ideología o visión política convencional, si algo puede repercutir de eso es que se predisponga de una ideología sin ideologías (Sarlo citado en Arlt, 2000), puesto que el extremismo político resulta en Arlt una pieza de la atmósfera dentro de la narración, el lugar para describir el accionar de la ridícula simulación de entender la política desde dos bandos aparentemente opuestos (extrema izquierda-extrema derecha). Más allá de sobreexponer antes que otro autor de la literatura latinoamericana, los posibles desastres de un fascismo o un socialismo nacionalista entreviendo designaciones directas: «Mussolini», «Lenin», «El Ku-Kux-Klan», las novelas de Arlt suscitan la convalecencia que se recrea en la voz de sus personajes, una intromisión caótica al espacio, engastado en lo social como atrevimiento y parte del problema de su literatura; desarticulación de la monogamia con un tipo único de rótulos, contradiciendo lo

$9 \quad$ Es decir, tiene la experiencia de saber, puesto que saber implica experiencia, y Artl, al igual que Steiner (2012), sabe que lo existencial antecede a lo cognitivo. 
político o concibiéndolo como multiplicidad en fase larval:

Con mi pensamiento se podría escribir una historia tan larga como la de la humanidad -decía otra vez-. Más larga aún. No sé si existo o no -escribió en su libreta-. Sé que vivo sumergido en el fondo de una desesperación que no tiene puestas de sol, y que es como si me encontrara bajo una bóveda, sobre la cual se apoya el océano." (Arlt, 2008, p. 74).

En otro sitio menciona su visión distópica: un pacifismo rebelde, a propósito de la cultura de naciones civilizadas que "discuten" la reducción de armamento militar: “¿Para qué sirve esa cultura, si en el año 1930, después de una guerra catastrófica como la de 1914, se discute un problema que debía causar espanto?" (Arlt, 2014, pp.32-33). No hay que olvidar que "logramos nuestra humanidad a través de actos de habla, nacidos de nuestro desarraigo" (Steiner, 2012, p. 96). La intempestividad de la novela arltiana, incluso mucho antes que Orwell, se adelanta críticamente a los desatinos políticos que están por advenir en esa parte del siglo XX. Su no-genialidad radica en que su proceso de creación literaria permite superar la simple visión de que su novelística se asienta en el uso de un vocabulario técnico enmarañado de un expresionismo vulgar; al contrario, es la metáfora del vocabulario de la ebullición de lo real, las exageraciones y las desarticulaciones con el lenguaje formal, la intromisión burlesca, el sabotaje a los dogmatismos, a la formalidad, lo que enriquece significativamente sus novelas $\mathrm{y}$ quizás gran parte de su obra. Si la novela acrecienta o interrumpe estados de ánimo, procesos mentales, sentimientos, emociones, donaciones de espíritu, ideas, ¿no será acaso que $L o s$ siete locos y Los lanzallamas de Arlt reproducen esa actitud del ser creador nietzscheano: duro, doloroso, cohibido, guerrero, difícil de entender para una racionalidad judeocristiana-capitalista-nihilista que procura siempre beber de las fuentes de la decadencia? (Nietzsche, 2000; Onfray, 2018).

Arlt comparte con Nietzsche que la actividad artística o creadora trata de hablar del sí mismo desde un paseo agreste y solitario (Nietzsche, 2009, p. 25), pero se aparta del pensador alemán en la medida en que no busca ampliar la comprensión del pensamiento humano, sino expresar enérgicamente desde su novelística el sentido de la vida que el mismo Nietzsche buscó en la literatura. Con esto, se desentierran dos formas de pensar la novela y la ficción. La primera es su posibilidad de hundimiento en la alteración antropológica y filosófica, la escritura filosófica, que no es siempre un tratado sistemático, tiene un trasfondo que la con- vierte en "autobiografía intelectual y espiritual", que interroga crudamente por el sentido de lo humano, ejemplos: San Agustín, Rousseau, Hegel, Heidegger, Nietzsche, Kierkegaard, Freud, lo que quiere decir que el sentido provisto por la escritura no depende de una forma por entero racional (Steiner, 2012). "La ficción es la antítesis, a modo de canto de sirena, de las verdades racionales" (Steiner, 2012, p. 87). La segunda, su figuración estético-subversiva por medio del despliegue de las imágenes del lenguaje que considera insolentes o con un alto grado de peligrosidad en relación con el Otro.

Las imágenes del lenguaje combinan el Yo y el Otro, de maneras insospechadas, y estas imágenes nunca son indiferentes a la existencia y giran en lo irrepetible. Las palabras en la novela se encuentran iluminadas por las palabras ajenas-otras dichas al respecto (Bajtín, 2015, p. 145); la orientación de las palabras en la novela lleva un rumbo agitado, enredado y tenso, toman como punto de partida otras palabras y otras más, y se chocan e interceptan en complejas interrelaciones, buscan sedimentar sus estratos semánticos, haciendo compleja y hasta agresiva su expresión (Bajtín, 2015, p. 146). La novela es la exploración delirante del sí mismo filtrada en otra exploración que ya tuvo filtraciones. Y con Arlt la novela accede al contra- 
bando o intercambio desequilibrado de fuerzas, la peligrosidad de las vociferaciones y los torbellinos que se acrecientan cuando se entierran o finalizan en la desolación o en la estela de un espanto humanizado en una perpetua de-formación.

Una migaja más: lo esencial de Los Siete Locos y Los Lanzallamas posiblemente sea el no tener ningún atributo más que el acrecentamiento de fuerzas en la exploración rediviva del ser humano, que casi siempre se oculta bajo la túnica de una rigurosa tristeza, para luego renacer como alegría que ha advenido con la experiencia de la peligrosidad.

Sobre la vida del escritor, basta ese grado de misterio que todavía ronda su existencia. Aunque cada vez asoman más apuntes biobibliográficos e incluso testimonios y entrevistas a familiares, donde se ofrece la imagen de un padre de familia que adoraba armar y salir a volar cometa con su hija.

Si existe un deber en el escritor, es el de invertir o transvalorar las relaciones de fuerzas para proporcionar un sabotaje al alma, a la claridad, un sabotaje incluso a lo que se considera simultáneamente destrozado.

\section{Conclusiones}

No solo los genios escriben. La responsabilidad del escritor es no perder la intensidad del carácter en el intento. Mantener la grandeza de lo íntimo, eso es, sus superficies. Desear profundamente una realidad, implica alcanzar tarde o temprano otra realidad, y eso hace parte del despertar con vida y con palabras para cruzar o replegarse en el tiempo. El sentido de lo trágico es fundamental no solo en lo literario, sino también en la experiencia de la vida, porque para realizar cualquier ideal es necesario enfrentarse a todos los demás ideales.

El entusiasmo por algo, no tanto por el sí mismo, sino por crear intempestivamente, crear algo incluso siguiendo las insólitas visiones de la escritura filosófica de Nietzsche: puro suspenso en el deseo de ir más allá del bien y del mal. Resistir en el compromiso de la voluntad de creación, es la manera de transfigurar el nihilismo adornado de religión, de política y de ciencia. Arlt tiene esta experiencia literaria y como lector de Nietzsche interpreta el sentido de lo trágico desde la posibilidad de la literatura, y acrecienta la voluntad creadora que consuma su obra.

La creación literaria, la molestia de la literatura, cada vez tiene que hacerse más persistente, subterránea, no puede quedar ningún rincón del alma humana por fuera del roce o la penetración de la palabra literaria. La persistencia en el intento creativo y la sabiduría de lo trágico arden en las novelas de Roberto Arlt. Para finalizar, un esbozo de esa no-genialidad arltiana que invita a replegar más preguntas, a confeccionar mayores intensidades, a proponer más escrituras, a permanecer en el relámpago creativo, pero también en el trueno que desfigura el eco de todo porvenir abrumado de claridad:

Ventana iluminada de las tres de la mañana. Si se pudiera escribir todo lo que se oculta tras tus vidrios biselados o rotos, se escribiría el más angustioso poema que conoce la humanidad. Inventores, rateros, poetas, jugadores, moribundos, triunfadores que no pueden dormir de alegría. Cada ventana iluminada en la noche crecida es una historia que aún no se ha escrito (Arlt, 2014, p. 60). 


\section{Bibliografía}

Amícola, J. (1994). Astrología y fascismo en la obra de Roberto Arlt. Buenos Aires: Beatriz Viterbo.

Arlt, R. (1981). Obra completa. Buenos Aires: Lohlé

Arlt, R. (2000). Los siete locos / Los Lanzallamas. Edición crítica, Goloboff, M. (coord.). Nanterre Cedex: Archivos.

Arlt. R. (2008). Los lanzallamas. Buenos Aires: Losada.

Arlt, R. (2014). Elogio de la vagancia. Santiago de Chile: LOM.

Arlt, R. (2015). Los siete locos. Madrid: Eneida.

Bajtín, M. (2015). Yo también soy (fragmentos sobre el otro). Buenos Aires: Godot.

Bataille, G. (2007). El erotismo. Barcelona: Tusquets.

Bataille, G. (2015). La felicidad, el erotismo y la literatura. Buenos Aires: Adriana Hidalgo.

Blanchot, M. (2005). El libro por venir. Madrid: Trotta.

Bloom, H. (1995). El canon occidental. La escuela y los libros de todas las épocas. Barcelona: Anagrama.

Bloom, H. (2005). ¿Dónde se encuentra la sabiduría? Buenos Aires: Taurus.

Bloom, H. (2011). Anatomía de la influencia. Madrid: Taurus.

Carbone, R. (2007). Imperio de las obsesiones. Los siete locos de Roberto Arlt: un grotexto. Buenos Aires: Editorial Universidad Nacional de Quilmes.

Cervera, V. (2009). El infierno de la mediocridad, de Roberto Arlt a Juan Carlos Onetti. Revista Monteagudo, 14, 59-78.

Darío, R. (1901). Prosas profanas y otros poemas. París: Vda. de C. Bouret. Recuperado el 12 de octubre de 2018, de http://cdigital.dgb.uanl.mx/la/1080011102/1080011102.PDF

Goloboff, M. (2002). Roberto Arlt: la máquina literaria. Revista de literaturas modernas, 32, 107-115. Recuperado el 7 de septiembre de 2018, de http://bdigital.uncu.edu.ar/1450.

Laplanche, J., \& Pontalis, J. (1981). Diccionario de psicoanálisis. Barcelona: Labor.

Nietzsche, F. (2000). La voluntad de poder. Madrid: Edaf. 
Nietzsche. F (2005). Así hablaba Zaratustra. Bogotá: Panamericana.

Nietzsche, F. (2009). Escritos de Turín. Cartas y notas de locura (fragmentos póstumos, 1888). Madrid: Biblioteca Nueva.

Onfray, M. (2018). Decadencia. Bogotá: Planeta.

Piglia, R. (2000). Crítica y ficción. Buenos Aires: Seix Barral.

Silva, J. (1996). Obra completa. Madrid: Allca XX.

Spivak, G. (2009). La muerte de una disciplina. Xalapa: Universidad Veracruzana.

Steiner, G. (2012). La poesía del pensamiento. México: Fondo de Cultura Económica.

Vallejo, F. (2008). Almas en pena Chapolas negras. Bogotá: Alfaguara.

Žižek, S. (2009). Sobre la violencia. Barcelona: Paidós. 